\title{
Interactive comment on "Biogeochemical evidence of anaerobic methane oxidation and anaerobic ammonium oxidation in a stratified lake using stable isotopes" by Florian Einsiedl et al.
}

Florian Einsiedl et al.

f.einsiedl@tum.de

Received and published: 15 May 2020

The comment was uploaded in the form of a supplement:

https://www.biogeosciences-discuss.net/bg-2020-18/bg-2020-18-AC2-supplement.pdf

Interactive comment on Biogeosciences Discuss., https://doi.org/10.5194/bg-2020-18, 2020. 